\title{
Demand for obstetric care and density of health resources for childbearing age Mexican women
}

\author{
Javier Valdés-Hernández, ${ }^{1}$ Aldelmo E. Reyes-Pablo, ${ }^{2}$ Eduardo Navarrete-Hernández ${ }^{3}$ and \\ Sonia Canún-Serrano ${ }^{4}$

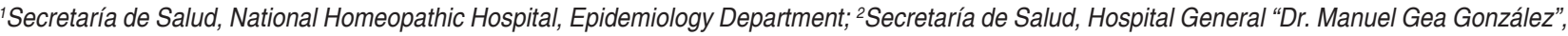 \\ Obstetrics \& Gynecology Division; 'Instituto Mexicano del Seguro Social, Epidemiological Surveillance Coordination, Hospital Epidemiology Division; \\ ${ }^{4}$ Secretaría de Salud, Hospital General "Dr. Manuel Gea González", Medical Genetics Division. Mexico City, Mexico
}

\begin{abstract}
Introduction: In Mexico, there is an increase recorded in the number of $C$-sections, as well as inequity and inequality in the distribution of resources for obstetric care. Objective: To identify the states and municipalities in Mexico that concentrate the demand for obstetric care and the $C$-section rates and their relationship with health resources and women of childbearing age (WCBA). Method: Births of the 2008-2017 period were recorded, grouped into five municipal strata, as well as 2017 health resources and WCBA. Results: The 2008-2017 national rate of C-sections was 45.3/100 births; 95 and $97 \%$ of births and $C$-sections were concentrated in the "very high" stratum, where $80 \%$ or more of health resources were used, with overuse standing out. The density of health resources assigned to WCBAs reflected inequity and inequality. Conclusions: The high concentration of obstetric demand and health resources supply could entail a higher recurrence of $C$-sections. Policies for $C$-section reduction should consider proper organization and administration of health resources.
\end{abstract}

KEY WORDS: Maternal health services. Cesarean sections. Health resources. Woman of childbearing age.

\section{Demanda de atención obstétrica, cesáreas y densidad de recursos en salud para la población femenina en edad fértil de México}

\section{Resumen}

Introducción: México registra aumento de las cesáreas e inequidad y desigualdad en la distribución de recursos para la atención obstétrica. Objetivo: Identificar las entidades y municipios en México que concentran la demanda de atención obstétrica y tasas de cesáreas y su relación con los recursos en salud y mujeres en edad fértil (MEF). Método: Se registraron los nacimientos del periodo 2008-2017, agrupados en cinco estratos municipales, y los recursos en salud y MEF de 2017. Resultados: La tasa nacional de cesáreas 2008-2017 fue de 45.3/100 nacimientos; 95 y 97 \% de los nacimientos y cesáreas se concentraron en el estrato "muy alto", en el cual se utilizó 80 \% o más de los recursos en salud y destacó la sobreutilización. La densidad de recursos en salud destinados a las MEF reflejó inequidad y desigualdad. Conclusiones: La alta concentración de la demanda obstétrica y oferta de los recursos en salud pudiera conllevar mayor recurrencia a la cesárea. En las políticas de reducción de cesáreas es necesario considerar la organización y administración adecuadas de los recursos en salud.

PALABRAS CLAVE: Servicios de salud materna. Cesáreas. Recursos en salud. Mujeres en edad fértil. 


\section{Introduction}

There are two routes whereby a delivery is solved: vaginal delivery or cesarean section (C-section). Regardless of the route, there is a natural risk for the mother and the fetus, and the obstetrician must therefore judge case by case which option is best for both..$^{1,2}$

$\mathrm{C}$-section is an incision in the abdominal and uterine walls that is intended to extract the living or dead fetus of 22 or more weeks of gestation, as well as the placenta and its annexes. It is the most common surgical procedure in obstetrics departments and its indication is the responsibility of the specialist in that area in daily practice. ${ }^{3,4}$

The indications for $\mathrm{C}$-section are precise and its only purpose is to ensure the mother-child binomial health, and thus this surgical procedure should only be used in women with high-risk deliveries. ${ }^{2,5,6}$ When it is carried out without the precise indications being complied with, the risks outweigh the benefits, which generates complications for women, violations of their reproductive rights and additional costs for the health system. ${ }^{7,8}$

The cesarean section rate (CSR) is a multidimensional indicator of hospital performance that assesses adequate medical care, mother-child safety and efficiency in the use of resources. According to the World Health Organization, the rate of necessary $\mathrm{C}$-sections is estimated to range between 10 and $15 \%$ of deliveries, while the CSR to reduce maternal-neonatal health risks ranges from 15 to $20 \%$.

Since 2000, an increase in CSR and its related factors has been reported in Mexico. ${ }^{9-12}$ With regard to clinical factors, in a review of 3232 medical records from the Mexican Institute of Social Security for the 1997-1999 period, 434 diagnostic expressions were noted, a heterogeneity that contrasted with institutional regulations in force, which established 59 specific indications. ${ }^{13}$

Differential CSRs have been referred when comparing different states of the country according to their degree of marginalization; the highest rates show a positive association with socioeconomic development: the lower the marginalization, the higher the CSR and vice versa. ${ }^{14}$

Studies on the organization of health services have found that CSRs are higher in the private than in the public sector, and that, in the latter, the CSR is higher in social security institutions than in those that look after unaffiliated population. . $^{10,14}$

In Mexico, iniquity and inequality in the distribution of health resources in general and specifically for obstetric care have been pointed out. . $^{14-16}$
Regarding the size of hospitals, Campero et al. identified that the probability of $\mathrm{C}$-section in a woman who requires obstetric care increases according to the size of the hospital from 10 beds on. ${ }^{17}$

Since 1983, several constitutional reforms have been carried out in Mexico in order to achieve the right to health protection and universal health coverage; however, inequality gaps persist. One of the causes is the supply of health resources, which is governed by social demand for medical care rather than by demographic and health requirements, ${ }^{18}$ which results in divergences in their use or efficiency, estimated as the volume of actions per unit of available health resources and the density of health resources (DHR), which refers to the ratio between the resources available to meet health needs and the target population they are directed to, even when they are not necessarily available at a given moment for that population. ${ }^{15}$

\section{Objectives}

- To identify the states and municipalities where the highest demand for obstetric care is concentrated, considered on the basis of the births recorded in the 2008-2017 period and the highest C-section rates, through stratification and mapping of information.

- To analyze the statistical relationship between the municipal strata according to the demand for obstetric care and C-sections and the efficiency of health resources in the municipalities.

- To identify the municipalities where the highest number of women of childbearing age (WCBA) aged 15 to 44 years is concentrated through municipal stratification and its statistical and geospatial relationship with the demand for obstetric care and C-sections and DHR per municipality.

\section{Method}

CSRs were calculated by states and municipalities according to the natality databases of the National Institute of Statistics and Geography (INEGI - Instituto Nacional de Estadística y Geografía) and the Ministry of Health (SSa - Secretaría de Salud) for the 20082017 period. Births of 22 or more weeks of gestation and $\geq 500 \mathrm{~g}$ weight were taken into account.

For the calculation of the CSR, the state and municipality of birth, the place where pregnant women 
requested and received the delivery care were taken into account.

The analysis by state of birth and annual CSR showed no significant differences, and the information for the period was therefore accumulated; the same procedure was used in the analysis by municipalities with the purpose to stabilize the CSRs.

For the summary and analysis of data by states and municipalities, births and CSRs were grouped by strata: very low $(\mathrm{VL})$, low $(\mathrm{L})$, middle $(\mathrm{M})$, high $(\mathrm{H})$ and very high $(\mathrm{VH})$. The stratification method was by percentiles. Stratification according to the number of births was used as the basis of the analysis for the grouping of the remaining data.

A concordance study between strata by birth and C-section was performed separately for both the states and municipalities in order to identify the relationship between both variables.

For better representation of some data, mapping was used. For the generation of maps, the Digital Map of Mexico program, version 6.3.0, was used, as well as the map layers of all 32 states of the country and their 2458 municipalities developed by INEGI.

The 2017 Health Resources data were acquired from the SSa General Directorate of Health Information and those for WCBA, from the 2017 projections of the National Population Council.

In order to analyze the statistical significance of differences, CSR mean comparisons were performed by strata using error plots and single-factor analysis of variance (ANOVA). The chi-square test was also used for the comparison of CSRs by strata.

\section{Results}

The number of births with state of birth records was $20,179,539$ (Fig. 1). The $\mathrm{VH}$ and $\mathrm{H}$ strata concentrated $67.9 \%$ of births, as well as $69.5 \%$ of $9,141,552$ C- sections performed during the period.

A national CSR of $45.3 / 100$ births was estimated. By states, the CSR ranged from 31.2 to $52.2 / 100$ births. The five states with the highest CSRs were Nuevo León, Yucatán, Sinaloa, Mexico City and Tamaulipas, while those with the lowest CSRs were San Luis Potosí, Zacatecas, Nayarit, Chiapas and Durango.

By strata, no differences in rates were identified, which ranged from 42.5 to $47.6 / 100$ births, not statistically significant according to the mean contrast plot and the ANOVA. The error plot shows CSR wide intervals for each stratum, which overlap with the opposites. The chi-square test for CRSs showed no significant differences between strata.

Geospatial contrast of births and CSR data shows that stratifications barely reached a concordance of $6.3 \%$ (Fig. 1).

Births with a municipal registry were $20,176,197$ (Fig. 2). There were 109 municipalities (4.43\%) with no data.

According to stratification, births and C-sections were concentrated in the $\mathrm{VH}$ stratum, which comprised 470 municipalities, with 95 and $97 \%$, respectively. Furthermore, CSR in that stratum was the highest: 46.3/100 births. CSR mean differences by strata are statistically significant, particularly when the VH stratum is compared with the others, according to the error plot and the ANOVA results. The narrow confidence intervals in the error plot for each stratum indicate stable figures inside. $\mathrm{VH}$ versus $\mathrm{H}$ stratum rate ratio is 1.58 and 5.1 in comparison with the VL stratum.

Concordance between municipalities of birth and CSR was $55.3 \%$; however, the analysis for each stratum showed a concordance of $93 \%$ between the $\mathrm{VH}$ strata of both groups. There was an almost perfect spatial correlation between the municipalities localized in the VH stratum of births and those of the CSR VH stratum, which increased the reliability of the trend towards concentrating the demand for obstetric care and $\mathrm{C}$-sections in these municipalities.

Table 1 describes the use of health resources by municipal strata according to the demand for obstetric care. In the majority of them, an upward trend was found that ran parallel to birth stratification: from lower to higher number of births, lower to higher use of health resources. With the exception of 11 items, the $\mathrm{VH}$ stratum concentrated $80 \%$ or more of resources. In those that had percentages lower than this limit, concentration was equal to or greater than $70 \%$ when the immediately lower stratum was added, with a predominance of the VH stratum, which confirms the trend towards a concentration of resources.

Table 2 shows the efficiency of health resources. Except for three items within births and two in C-sections, an ascending number of births or $\mathrm{C}$-sections was found per unit that ran parallel to birth stratification: from lower to higher birth stratification, lower to higher number of births or $\mathrm{C}$-sections per unit of health resources, which indicates overuse in the $\mathrm{VH}$ and underuse in the VL strata.

As for the distribution of WCBA by strata according to the number of births (Fig. 3), nearly $75 \%$ of WCBA were at the VH stratum, followed by the $\mathrm{H}$ 


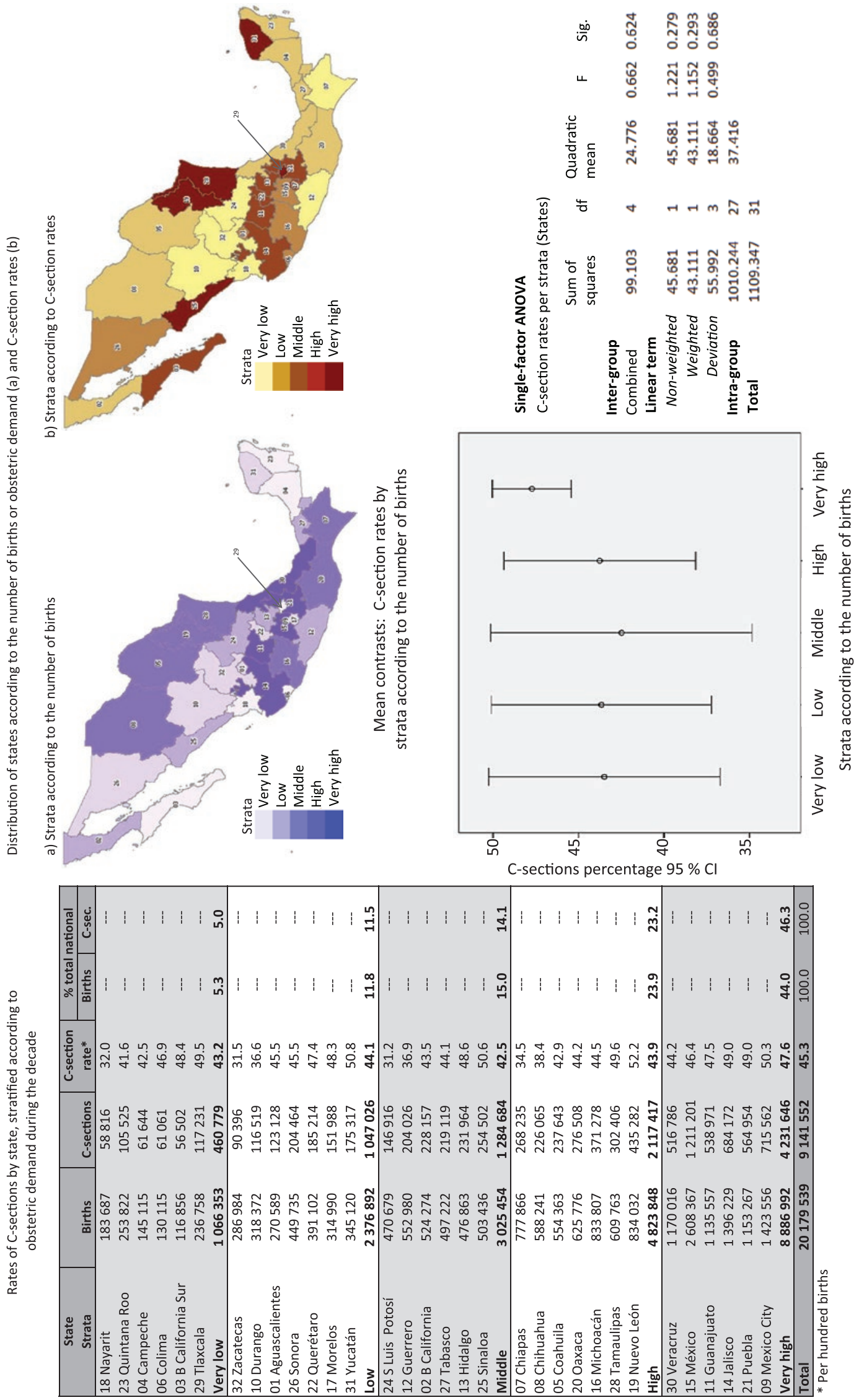

Figure 1. Obstetric demand (number of births) and C-section rates, nation-wise and by states. Mexico, 2008-2017. 


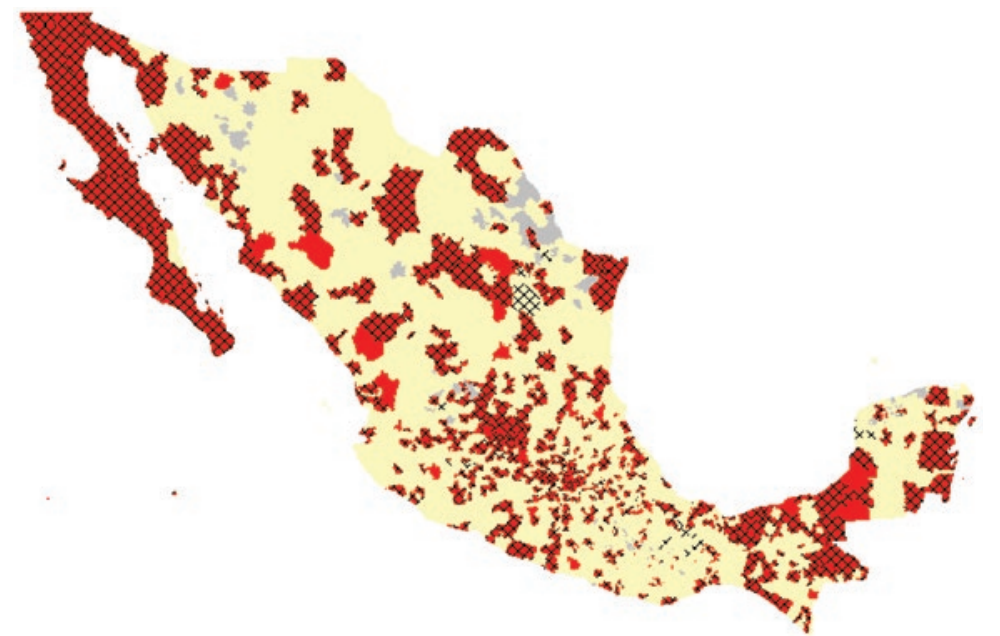

\begin{tabular}{|c|c|c|c|c|c|c|}
\hline \multirow{2}{*}{$\begin{array}{c}\text { Strata by number } \\
\text { of births }\end{array}$} & \multirow{2}{*}{$\begin{array}{c}\text { Municipalities* } \\
\mathrm{n}\end{array}$} & \multicolumn{2}{|c|}{ Births } & \multicolumn{2}{|c|}{ C-sections } & \multirow{2}{*}{$\begin{array}{l}\text { C-section } \\
\text { rates** }\end{array}$} \\
\hline & & $\mathrm{n}$ & $\%$ & $\mathrm{n}$ & $\%$ & \\
\hline \begin{tabular}{l|l} 
Very low \\
\end{tabular} & 470 & 1991 & 0.01 & 180 & 0.00 & 9.04 \\
\hline Low & 469 & 13965 & 0.07 & 678 & 0.01 & 4.85 \\
\hline Middle & 469 & 91544 & 0.45 & 8864 & 0.10 & 9.68 \\
\hline High & 471 & 910593 & 4.51 & 265964 & 2.91 & 29.21 \\
\hline Very high & 470 & 19158104 & 94.95 & 8864862 & 96.98 & 46.27 \\
\hline Total & 2349 & 20176197 & 100.00 & 9140548 & 100.00 & 45.30 \\
\hline
\end{tabular}

Municipalities at the "very high" stratum of C-section rates.

*109 municipalities with no data. Total municipalities in 2017: 2458

** Per hundred births
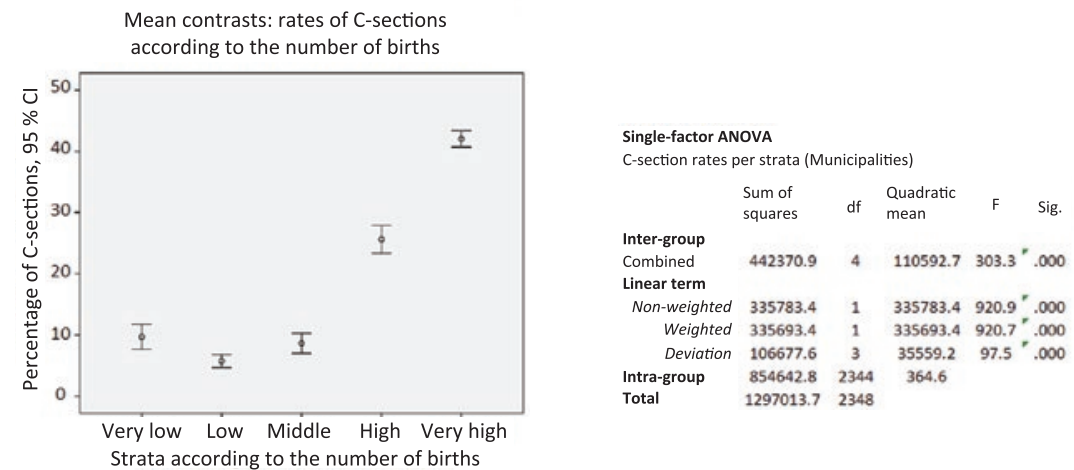

Figure 2. Obstetric demand and C-section rates distribution according to municipal strata and their geospatial coincidence. Mexico, $2008-2017$. Source: Bases de datos abiertas de nacimientos, INEGI/SSA, 2008-2017.

stratum, which together accounted for approximately $88 \%$. This distribution is geospatially illustrated on the map: it exceeds the territorial extension of the 470 municipalities where $95 \%$ of births are concentrated.

Women in the $\mathrm{VH}$ stratum who migrated for their care were $41.1 \%$, while $34.5 \%$ in the $\mathrm{H}$ stratum and $29.6 \%$ in the VL stratum did the same. The DHR figures for WCBA have a random behavior, since some of them reflect iniquity and inequality in the provision of resources, while there are also similar figures that would indicate equity and equality.

\section{Discussion}

Currently, ecological studies at the level of small areas are more convenient because they are more enlightening. ${ }^{19}$ With this approach, in our analysis we identified a high concentration in the demand for obstetric care and C-sections in 470 municipalities associated with the clustering of health resources. However, inequalities were observed in the use of health resources in the $\mathrm{H}$ and $\mathrm{VH}$ strata, with overuse due to the excessive demand for obstetric care. Regarding human resources for health, this relationship can be considered as an indicator of 
Valdés-Hernández J, et al.: Obstetric demand and health resources

Table 1. Health resources distribution by municipal strata according to the number of births or obstetric demand. Mexico, 2008-2017

\begin{tabular}{|c|c|c|c|c|c|c|c|c|c|c|c|}
\hline \multirow{3}{*}{ Health resources } & \multicolumn{11}{|c|}{ Strata according to the number of births } \\
\hline & \multicolumn{2}{|c|}{ Very low } & \multicolumn{2}{|c|}{ Low } & \multicolumn{2}{|c|}{ Middle } & \multicolumn{2}{|c|}{ High } & \multicolumn{2}{|c|}{ Very high } & \multirow[t]{2}{*}{ Total } \\
\hline & $\mathrm{n}$ & $\%$ & $n$ & $\%$ & $\mathrm{n}$ & $\%$ & $\mathbf{n}$ & $\%$ & $\mathrm{n}$ & $\%$ & \\
\hline Primary care units & 1228 & 5.9 & 1887 & 9.1 & 2969 & 14.4 & 4702 & 22.7 & 9883 & 47.8 & 20669 \\
\hline Secondary care units & 2 & 0.2 & 6 & 0.5 & 20 & 1.5 & 232 & 17.7 & 1050 & 80.2 & 1310 \\
\hline Hospitalization area & 2 & 0.1 & 9 & 0.5 & 29 & 1.7 & 260 & 14.8 & 1455 & 82.9 & 1755 \\
\hline Surgical unit & 0 & 0.0 & 1 & 0.1 & 12 & 1.0 & 208 & 17.7 & 951 & 81.1 & 1172 \\
\hline NICU & 0 & 0.0 & 0 & 0.0 & 1 & 0.3 & 8 & 2.3 & 333 & 97.4 & 342 \\
\hline Obstetrics and obstetric surgery area & 56 & 3.6 & 67 & 4.3 & 86 & 5.5 & 327 & 21.0 & 1021 & 65.6 & 1557 \\
\hline Neonatology and nursery area & 1 & 0.1 & 5 & 0.6 & 13 & 1.6 & 105 & 12.7 & 701 & 85.0 & 825 \\
\hline Operating rooms & 2 & 0.0 & 3 & 0.1 & 19 & 0.5 & 314 & 7.7 & 3714 & 91.7 & 4052 \\
\hline Delivery rooms & 100 & 3.8 & 169 & 6.4 & 214 & 8.1 & 528 & 20.0 & 1632 & 61.7 & 2643 \\
\hline Cribs for healthy newborns & 31 & 0.4 & 49 & 0.7 & 71 & 1.0 & 480 & 6.6 & 6599 & 91.3 & 7230 \\
\hline Total offices & 1864 & 2.5 & 2832 & 3.8 & 4410 & 5.9 & 9016 & 12.2 & 56036 & 75.6 & 74158 \\
\hline General medicine & 1508 & 3.9 & 2274 & 5.9 & 3457 & 8.9 & 6184 & 15.9 & 25355 & 65.4 & 38778 \\
\hline Obstetrics \& gynecology & 2 & 0.1 & 6 & 0.3 & 27 & 1.3 & 229 & 11.4 & 1746 & 86.9 & 2010 \\
\hline Pediatrics & 3 & 0.2 & 4 & 0.2 & 26 & 1.5 & 186 & 10.7 & 1527 & 87.5 & 1746 \\
\hline Total beds hospitalization area & 15 & 0.0 & 250 & 0.3 & 570 & 0.7 & 4074 & 4.7 & 82014 & 94.4 & 86923 \\
\hline General medicine & 3 & 0.2 & 6 & 0.4 & 42 & 2.9 & 540 & 36.9 & 874 & 59.7 & 1465 \\
\hline Obstetrics \& gynecology & 1 & 0.0 & 15 & 0.1 & 48 & 0.3 & 983 & 5.9 & 15533 & 93.7 & 16580 \\
\hline General and reconstructive surgery & 0 & 0.0 & 6 & 0.0 & 32 & 0.2 & 643 & 4.6 & 13347 & 95.1 & 14028 \\
\hline Pediatrics & 4 & 0.0 & 14 & 0.1 & 105 & 1.0 & 683 & 6.2 & 10131 & 92.6 & 10937 \\
\hline Labor area & 199 & 4.0 & 327 & 6.5 & 442 & 8.8 & 631 & 12.5 & 3438 & 68.3 & 5037 \\
\hline Postpartum recovery area & 0 & 0.0 & 8 & 7.8 & 14 & 13.6 & 4 & 3.9 & 77 & 74.8 & 103 \\
\hline Total physicians & 1078 & 2.1 & 1984 & 3.8 & 3528 & 6.7 & 8178 & 15.6 & 37605 & 71.8 & 52373 \\
\hline General practitioners & 189 & 1.0 & 210 & 1.1 & 261 & 1.4 & 824 & 4.3 & 17716 & 92.3 & 19200 \\
\hline Pediatricians & 19 & 0.2 & 6 & 0.1 & 26 & 0.2 & 398 & 3.7 & 10356 & 95.8 & 10805 \\
\hline Obstetrician-gynecologists & 14 & 0.2 & 3 & 0.0 & 31 & 0.3 & 408 & 4.5 & 8525 & 94.9 & 8981 \\
\hline Surgeons & 14 & 0.2 & 3 & 0.0 & 7 & 0.1 & 128 & 1.8 & 6986 & 97.9 & 7138 \\
\hline Anesthesiologists & 2 & 0.1 & 18 & 1.1 & 10 & 0.6 & 12 & 0.8 & 1531 & 97.3 & 1573 \\
\hline On training & 759 & 5.9 & 978 & 7.6 & 1235 & 9.6 & 2047 & 15.9 & 7854 & 61.0 & 12873 \\
\hline Residents & 96 & 0.6 & 127 & 0.8 & 264 & 1.7 & 794 & 5.1 & 14339 & 91.8 & 15620 \\
\hline Interns & 96 & 2.7 & 185 & 5.2 & 269 & 7.5 & 353 & 9.9 & 2673 & 74.7 & 3576 \\
\hline Undergraduate interns & 0 & 0.0 & 1 & 0.0 & 9 & 0.0 & 232 & 0.9 & 24287 & 99.0 & 24529 \\
\hline Total nurses & 740 & 0.5 & 1228 & 0.8 & 2682 & 1.8 & 7664 & 5.2 & 133671 & 91.6 & 145985 \\
\hline General nurses & 75 & 0.2 & 86 & 0.2 & 224 & 0.6 & 781 & 2.2 & 34647 & 96.7 & 35813 \\
\hline Obstetrics nurses & 1012 & 0.5 & 1354 & 0.7 & 2936 & 1.4 & 11220 & 5.4 & 191723 & 92.1 & 208245 \\
\hline
\end{tabular}

Source: Bases de datos abiertas de nacimientos INEGI/SSa, 2008-2017 and SSa 2017 health resources. NICU = Neonatal intensive care unit. 
Gaceta Médica de México. 2020;156

Table 2. Use of heath resources by municipal strata according to obstetric demand or number of births. México, 2008-2017

\begin{tabular}{|c|c|c|c|c|c|c|}
\hline \multirow[t]{3}{*}{ Health resources } & \multicolumn{6}{|c|}{ Strata according to the number of births } \\
\hline & Very low & Low & Middle & High & Very high & Total \\
\hline & $\begin{array}{c}\mathrm{HR} / \mathrm{B} \text { or } \mathrm{C} \\
\text { ratio }\end{array}$ & $\begin{array}{l}\mathrm{HR} / \mathrm{B} \text { or } \mathrm{C} \\
\text { ratio }\end{array}$ & $\begin{array}{c}\mathrm{HR} / \mathrm{B} \text { or } \mathrm{C} \\
\text { ratio }\end{array}$ & $\begin{array}{l}\mathrm{HR} / \mathrm{B} \text { or } \mathrm{C} \\
\text { ratio }\end{array}$ & $\begin{array}{c}\mathrm{HR} / \mathrm{B} \text { or } \mathrm{C} \\
\text { ratio }\end{array}$ & $\begin{array}{l}\mathrm{HR} / \mathrm{B} \text { or } \mathrm{C} \\
\text { ratio }\end{array}$ \\
\hline Number of births & 1991 & 13965 & 91544 & 910593 & 19158104 & 20176197 \\
\hline Obstetrics and obstetric surgery area & 36 & 208 & 1064 & 2785 & 18764 & 12958 \\
\hline Delivery rooms & 20 & 83 & 428 & 1725 & 11739 & 7634 \\
\hline General medicine offices & 1 & 6 & 26 & 147 & 756 & 520 \\
\hline Obstetrics \& gynecology offices & 996 & 2328 & 3391 & 3976 & 10973 & 10038 \\
\hline Obstetrics \& gynecology beds & 1991 & 931 & 1907 & 926 & 1233 & 1217 \\
\hline Labor area beds & 10 & 43 & 207 & 1443 & 5572 & 4006 \\
\hline Postpartum recovery beds & 0 & 1746 & 6539 & 227648 & 248807 & 195885 \\
\hline General practitioners & 11 & 67 & 351 & 1105 & 1081 & 1051 \\
\hline Obstetrician-gynecologists & 142 & 4655 & 2953 & 2232 & 2247 & 2247 \\
\hline Anesthesiologist physicians & 996 & 776 & 9154 & 75883 & 12513 & 12827 \\
\hline Medical interns & 21 & 75 & 340 & 2580 & 7167 & 5642 \\
\hline Undergraduate interns & 0 & 13965 & 10172 & 3925 & 789 & 823 \\
\hline Nurses & 3 & 11 & 34 & 119 & 143 & 138 \\
\hline General nurses & 27 & 162 & 409 & 1166 & 553 & 563 \\
\hline Obstetrics nurses & 2 & 10 & 31 & 81 & 100 & 97 \\
\hline Number of C-sections & 180 & 678 & 8864 & 265964 & 8864862 & 9140548 \\
\hline Obstetrics and obstetric surgery area & 3 & 10 & 103 & 813 & 8683 & 5871 \\
\hline Delivery rooms & 2 & 4 & 41 & 504 & 5432 & 3458 \\
\hline General medicine offices & 0 & 0 & 3 & 43 & 350 & 236 \\
\hline Obstetrics \& gynecology offices & 90 & 113 & 328 & 1161 & 5077 & 4548 \\
\hline Obstetrics \& gynecology beds & 180 & 45 & 185 & 271 & 571 & 551 \\
\hline Labor area beds & 1 & 2 & 20 & 421 & 2578 & 1815 \\
\hline Postpartum recovery beds & 0 & 85 & 633 & 66491 & 115128 & 88743 \\
\hline General practitioners & 1 & 3 & 34 & 323 & 500 & 476 \\
\hline Obstetrician-gynecologists & 13 & 226 & 286 & 652 & 1040 & 1018 \\
\hline Anesthesiologist physicians & 90 & 38 & 886 & 22164 & 5790 & 5811 \\
\hline Medical interns & 2 & 4 & 33 & 753 & 3316 & 2556 \\
\hline Undergraduate interns & 0 & 678 & 985 & 1146 & 365 & 373 \\
\hline Nurses & 0 & 1 & 3 & 35 & 66 & 63 \\
\hline General nurses & 2 & 8 & 40 & 341 & 256 & 255 \\
\hline Obstetrics nurses & 0 & 1 & 3 & 24 & 46 & 44 \\
\hline
\end{tabular}

Source: Bases de datos abiertas de nacimientos INEGI/SSA 2008-2017 and SSa 2017 health resources. HR = health resources. B = births, C = C-sections. 


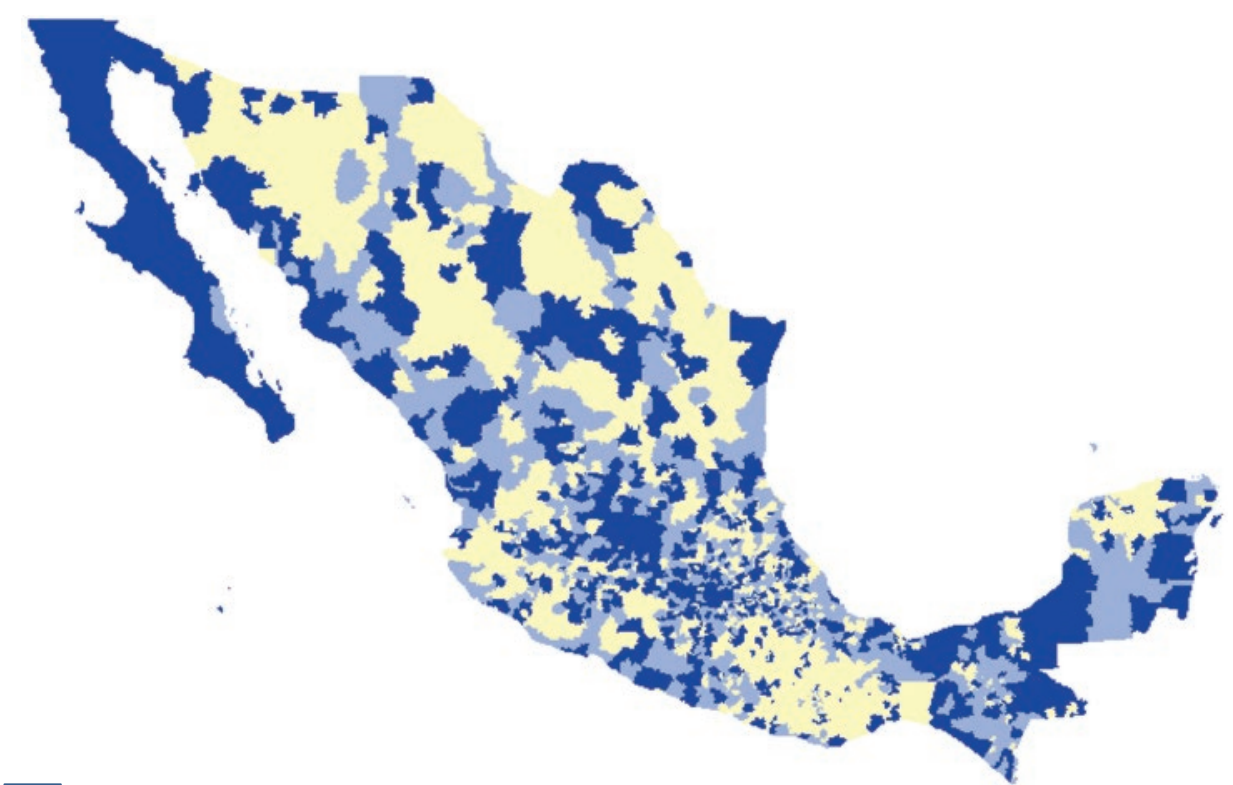

Municipalities where $88 \%$ of women aged 15 to 44 years reside

Municipalities where $95 \%$ of deliveries were attended to in the studied period

\begin{tabular}{|c|c|c|c|c|c|c|}
\hline \multirow[t]{2}{*}{ Indicator } & \multicolumn{6}{|c|}{ Strata according to the number of births } \\
\hline & Very low & Low & Middle & High & Very high & Total \\
\hline Women aged 15 to 44 years & 620,148 & $1,122,688$ & $1,883,577$ & $3,900,111$ & $22,350,537$ & $29,877,062$ \\
\hline Percentage & 2.1 & 3.8 & 6.3 & 13.1 & 74.8 & 100.0 \\
\hline $\begin{array}{l}\text { Percentage of births with usual } \\
\text { residence other than the } \\
\text { municipality of care }\end{array}$ & 29.6 & 20.6 & 18.3 & 34.5 & 41.1 & 40.7 \\
\hline \begin{tabular}{|c|}
2017 health resources \\
\end{tabular} & \multicolumn{6}{|c|}{ Density of health resources use by women aged $15-44$ years } \\
\hline Obstetrics and ob-surgery area & 11,074 & 16,757 & 21,902 & 11,927 & 21,891 & 19,189 \\
\hline Delivery rooms & 6,201 & 6,643 & 8,802 & 7,387 & 13,695 & 11,304 \\
\hline General medicine offices & 411 & 494 & 545 & 631 & 882 & 770 \\
\hline Obstetrics \& gynecology offices & 310,074 & 187,115 & 69,762 & 17,031 & 12,801 & 14,864 \\
\hline Obstetrics \& gynecology beds & 620,148 & 74,846 & 39,241 & 3,968 & 1,439 & 1,802 \\
\hline Beds in labor area & 3,116 & 3,433 & 4,261 & 6,181 & 6,501 & 5,932 \\
\hline Beds in postpartum recovery & 0 & 140,336 & 134,541 & 975,028 & 290,267 & 290,069 \\
\hline General practitioners & 3,281 & 5,346 & 7,217 & 4,733 & 1,262 & 1,556 \\
\hline Obstetrician-gynecologists & 44,296 & 374,229 & 60,761 & 9,559 & 2,622 & 3,327 \\
\hline Physician anesthesiologists & 310,074 & 62,372 & 188,358 & 325,009 & 14,599 & 18,994 \\
\hline Medical interns & 6,460 & 6,069 & 7,002 & 11,048 & 8,362 & 8,355 \\
\hline Undergraduate interns & 0 & \begin{tabular}{|l|}
$1,122,688$ \\
\end{tabular} & 209,286 & 16,811 & 920 & 1,218 \\
\hline Nurses & 838 & 914 & 702 & 509 & 167 & 205 \\
\hline General nurses & 8,269 & 13,055 & 8,409 & 4,994 & 645 & 834 \\
\hline Obstetrics nurses & 613 & 829 & 642 & 348 & 117 & 143 \\
\hline
\end{tabular}

Figure 3. Relationship between health resources and women aged 15 to 44 years by municipal strata according to obstetric demand or number of births. Mexico, 2008-2017. Source: Bases de datos abiertas de nacimientos, INEGI/SSA, 2008-2017. SSa 2017 health resources and National Population Council 2017 population estimates.

productivity. As for the results, supersaturation in obstetrics and gynecology departments might lead to a higher use of C-section as a strategy to free beds in the delivery rooms, considering the effective time of care required for a vaginal delivery in comparison with a C-section.

Since its creation in the 1950s, the Mexican medical model has focused on curative or problem-solving care ${ }^{20}$ which places the delivery rooms in the hospital setting, privileging secondary and tertiary over primary care, thus transforming obstetric practice into a matter of "medical specialty" in parallel to the process of displacement of general medicine: there are 1.7 medical specialists for each general practitioner (Table 1). 
During the study period, $98 \%$ of births were attended to in hospitals; $63 \%$ of the obstetrics and obstetric surgery areas, $93 \%$ of neonatology and nursery areas, $95 \%$ of operating rooms, $56 \%$ of delivery rooms and $93 \%$ of the cribs for healthy newborns are in secondary care facilities. In contrast, $92 \%$ of general medicine offices, $83 \%$ of general practitioners and $3 \%$ of family medicine specialists are found in primary care units.

The results confirm the distributive health policy implemented in Mexico, which overlooks the criterion of the potential user population for the provision of services. This study highlighted the uneven DHR in relation to the number of WCBA, which might explain the high percentage of pregnant women inter-municipal migration for childbirth care to municipalities with more resources or that were available at the time they were required. Two out of every five childbirths were extraterritorial to the place of maternal usual residence. Although local density of resources in the $\mathrm{L}$ and VL birth strata was better, there was a high percentage of care in other municipalities, either because health resources were concentrated there or because local obstetric care services were not operating at the time they were required.

According to the results, inadequate planning of health resources for obstetric care and the medical care model are added to the known factors associated with high CSR and thus, considering these dimensions in the development of public policies aimed at reducing $\mathrm{C}$-section rates is also required.

In this reengineering, designing primary care units with an acceptable area for the care of imminent or low-risk deliveries would be necessary, considering the distribution of the demanding population and the necessary health resources, in addition to strengthening primary care services, which also requires improving general practitioners capabilities and the quality of care.

Furthermore, estimating an adequate and rational CSR according to the context of the country is necessary, which will serve as a reference for further evaluations on $\mathrm{C}$-sections, under the current regulations of delivery care. In addition, rational indicators of productivity and use of health resources are required.

Changes in the demographic and epidemiological profile of the Mexican population are foreseeable for the years to come. The health system needs to be adjusted to respond to these changes, especially including the composition of human resources, particularly towards vaginal route obstetric care.
The approach of this research report offers novel and important conclusions within the context the country is living in.

\section{Acknowledgements}

To obstetrician-gynecologists Josué Jáuregi Valdez and Didilia Elena Bejarano Velázquez, for their comments on C-sections at public hospitals, which enrichened this work.

\section{References}

1. American College of Obstetricians and Gynecologists; Society for Maternal-Fetal Medicine; Caughey AB, Cahill AG, Guise JM, Rouse DJ. Safe prevention of the primary cesarean delivery. Am J Obstet Gynecol. 2014;210:179-193.

2. Villanueva-Egan LA. Operación cesárea: una perspectiva integral. Rev Fac Med UNAM. 2004;47:246-250.

3. Lee SI. Operación cesárea: estudio de causas y tendencias en un hospital de segundo nivel. Rev Med IMSS. 2004:42:199-204.

4. Muñoz-Enciso JM, Rosales-Aujang E, Domínguez-Ponce G, Serrano-Díaz CL. Operación cesárea: ¿indicación justificante o preocupación justificada? Ginecol Obstet Mex. 2011;79:67-74.

5. Guía de práctica clínica. Reducción de la frecuencia de operación cesárea México: Instituto Mexicano del Seguro Social; 2014.

6. Suárez-López L, Campero L, de la Vara-Salazar E, Rivera-Rivera L, Hernández-Serrato MI, Walker D, et al. Características sociodemográficas y reproductivas asociadas con el aumento de cesáreas en México. Salud Publica Mex. 2013;55:S225-S234.

7. Declaración sobre tasas de cesárea. Suiza: Organización Mundial de la Salud/Departamento de Salud Reproductiva e Investigación. 2015

8. Rosales-Aujang E, Felguérez-Flores J. Repercusión demográfica de la operación cesárea. Ginecol Obstet Mex. 2009;77:362-366

9. González-Pérez GJ, Vega-López MG, Cabrera-Piraval C, Muñoz A, VaIle A. Caesarean sections in Mexico: are there too many? Health Policy Plan. 2001;16:62-67.

10. Suárez L, Campero L, de la Vara E, Rivera L, Hernández Ml, Walker D, et al. Elevada recurrencia a las cesáreas: revertir la tendencia y mejorar la calidad en el parto. México: Instituto Nacional de Salud Pública; 2019.

11. Gómez-Dantés O, Sesma S, Becerril VM, Knaul FM, Arreola H, Frenk J. Sistema de salud de México. Sal Pub Mex. 2011;53:S220-S232.

12. Beltrán AP, Ye J, Moller AB, Zhang J, Gülmezoglu AM, Torloni MR. The increasing trend in caesarean section rates: global, regional and national estimates: 1990-2014. PLoS One. 2016;11:e0148343.

13. Velasco-Murillo V, Navarrete-Hernández E, Pozos-Cavanzo JL, Ojeda-Mijares RI, Cárdenas-Lara C, Cardona-Pérez JA. Indicaciones y justificación de las cesáreas en el Instituto Mexicano del Seguro Social. Gac Med Mex. 2000;136:421-431.

14. González-Pérez GJ, Vega-López MG, Cabrera-Piraval CE. Cesáreas en México: aspectos sociales, económicos y epidemiológicos. México: Centro Universitario de Ciencias de la Salud; 2011.

15. Ochoa-Moreno JA. Densidad de recursos para la atención de la salud de la población no derechohabiente en México, en 2013. México: Organización Panamericana de la Salud/Organización Mundial de la Salud/ Secretaría de la Salud/Comisión Nacional de Arbitraje Médico; 2016.

16. Alcalde-Rabanal JE, Nigenda G, Serván-Mori E, González-Robledo LM, Lozano R. Brechas en la disponibilidad de médicos y enfermeras especialistas en el sistema nacional de salud. Informe Final. México: Instituto Nacional de Salud Pública/Comisión Nacional de Seguridad/Dirección General de Calidad y Educación en Salud/Comité de Estudio de Necesidades de Formación de Recursos Humanos en Salud/Comisión Interinstitucional para la Formación de Recursos Humanos para la Salud; 2017.

17. Campero L, Hernández B, Leyva A, Estrada F, Osborne J, Morales S. Tendencias de cesáreas en relación con factores no clínicos en un centro de educación para el parto en la Ciudad de México. Salud Publica Mex. 2007;49:118-125.

18. Hernández-Palacios RD. Una prospectiva de la salud en México. Algunos aspectos del marco sociojurídico. Alegatos. 2007:65:47-56.

19. Silva-Ayçaguer LC, Benavides-Rodríguez A, Vidal-Rodeiro CL. Análisis espacial de la mortalidad en áreas geográficas pequeñas. El enfoque bayesiano. Rev Cubana Salud Publica. 2003;29:314-322.

20. Hernández-Llamas H. Historia de la participación del Estado en las instituciones de atención médica en México, 1935-1980. En: Ortiz-Quesada F (editor). Vida y muerte del mexicano. México: Ediciones Folios; 1982. 